OPEN ACCESS

Edited by:

Oleg Shupliakov,

Karolinska Institutet (KI), Sweden

Reviewed by:

Angela Di Giannatale,

Bambino Gesù Children Hospital

(IRCCS), Italy

Andrea Gazze,

Swansea University, United Kingdom

*Correspondence:

Roberto Furlan

furlan.roberto@hsr.it

Specialty section:

This article was submitted to

Molecular Medicine,

a section of the journal

Frontiers in Cell and Developmental

Biology

Received: 29 October 2020

Accepted: 21 December 2020

Published: 21 January 2021

Citation:

Marostica G, Gelibter S, Gironi M,

Nigro $A$ and Furlan R (2021)

Extracellular Vesicles in

Neuroinflammation.

Front. Cell Dev. Biol. 8:623039.

doi: 10.3389/fcell.2020.623039

\section{Extracellular Vesicles in Neuroinflammation}

\author{
Giulia Marostica, Stefano Gelibter, Maira Gironi, Annamaria Nigro and Roberto Furlan* \\ Division of Neuroscience, Institute of Experimental Neurology, San Raffaele Scientific Institute, Milan, Italy
}

Extracellular vesicles (EVs) are a heterogenous group of membrane-bound particles that play a pivotal role in cell-cell communication, not only participating in many physiological processes, but also contributing to the pathogenesis of several diseases. The term EVs defines many and different vesicles based on their biogenesis and release pathway, including exosomes, microvesicles (MVs), and apoptotic bodies. However, their classification, biological function as well as protocols for isolation and detection are still under investigation. Recent evidences suggest the existence of novel subpopulations of EVs, increasing the degree of heterogeneity between EV types and subtypes. EVs have been shown to have roles in the CNS as biomarkers and vehicles of drugs and other therapeutic molecules. They are known to cross the blood brain barrier, allowing CNS EVs to be detectable in peripheral fluids, and their cargo may give information on parental cells and the pathological process they are involved in. In this review, we summarize the knowledge on the function of EVs in the pathogenesis of multiple sclerosis (MS) and discuss recent evidences for their potential applications as diagnostic biomarkers and therapeutic targets.

Keywords: extracellular vesicles, neuroinflammation, biomarker, multiple sclerosis, therapeutic target

\section{INTRODUCTION}

Extracellular vesicles (EVs) are nano-sized vesicles released into different body fluids, heterogeneous in terms of origin, activities, compositions. Originally considered an in vitro artifact or useless cellular debris (Chargaff and West, 1946), they became an attractive object of research when they were shown to be an evolutionary conserved way of intercellular communication (Camussi et al., 2010; Tkach and Théry, 2016). Their precious cargo made of proteins, lipids, nucleic acids provide information of the cells and microenvironment where they are originally released.

Despite a huge advance in the knowledge of neuroinflammatory diseases, a biomarker tracking every pathogenetic step is still missing.

One of the most conceivable reason is the "hard-to-access" stage where neuroinflammation occurs. Brain and spinal cord are protected by the blood brain barrier (BBB), rather sequestered from the rest of the body and hard to be sampled.

Unsurprisingly, EVs produced by microglia, astrocyte, and other neural cells providing a snapshot of their original environment, have become the focus of thousands of studies investigating neuroinflammation, particularly in multiple sclerosis (MS).

Although recent studies have brought many advances in EV knowledge, different points still remain to be addressed. In this review we try to bridge conflicting data concerning classification, isolation, and detection techniques. Moreover, we deeply dissect EVs' role either as epiphenomenon of neuroinflammation (marker of disease) or direct culprits involved in pathogenetic mechanisms (contributory cause of disease). 


\section{EXTRACELLULAR VESICLES}

\section{Detection and Isolation}

Current approaches to identify and distinguish discrete populations of EVs are based on size, density, subcellular origin, and molecular composition (Raposo and Stoorvogel, 2013; Colombo et al., 2014; van Niel et al., 2018). Because of their overlapping physicochemical properties, classification of EVs is challenging and has produced a number of controversial results, stumbling blocks for their isolation and detection, lack of guidelines regarding their nomenclature are mainly responsible for this inconsistency. Moreover, increasing evidences highlight the existence of various subpopulations even within EV populations, suggesting that EVs are more complex entities than previously recognized and that they can be further classified into various subtypes (Lässer et al., 2018; Théry et al., 2018).

In recent years, technical advancements have led to the development of optimized methods for EV isolation and purification in attempt to elucidate the heterogeneous nature of secreted EVs and give a more comprehensive understanding on the properties of EV subtypes (Crescitelli et al., 2013; Lunavat et al., 2015; Kibria et al., 2016; Kowal et al., 2016; Willms et al., 2018). Several techniques of EV purification have been described including differential centrifugation, density gradient, ultrafiltration, polymer-based precipitation, immunoaffinity, and size exclusion chromatography, resulting in variable yield and purity of isolated EVs. Differential centrifugation remains by far the standard and the most widely used method to isolate EVs from biological fluids and media (Théry et al., 2006; Gardiner et al., 2016). This approach is often combined with density gradient flotation to efficiently eliminate copurified non$\mathrm{EV}$ material or EV fragments which arise during differential centrifugation (Karimi et al., 2018; Onódi et al., 2018; Théry et al., 2018; Lee et al., 2019). In a recent work, Jeppesen et al. (2019) redefined EV composition and differential sorting of protein, RNA, and DNA between EV and non-vesicular extracellular particles. They clarified the composition of exosomes, excluding several highly abundant cytosolic proteins (like GAPDH, ENO1, and PARK7/DJ1) as well as the proteins involved in the miRNA machinery that were thought to be incorporated. Several groups have performed subfractionation of EV preparations and identified vesicle subclasses in given EV samples based on RNA composition (Crescitelli et al., 2013; Lunavat et al., 2015) or protein profiling data (Kibria et al., 2016; Kowal et al., 2016; Willms et al., 2018). Addressing the EV heterogeneity, the Lötvall's group most recently provided a detailed categorization of tumor tissue-derived EV subpopulations, separated by size and density, which showed different RNA composition and protein profile (Crescitelli et al., 2020). Interestingly, both shared and unique protein markers of EV subpopulations were found. Recently, by using asymmetric-flow field-flow fractionation, Zhang Y. et al. (2018) identified a new class of nanoparticles of $20-50 \mathrm{~nm}$ in diameter, named exomeres, which lack an external membrane.

A standardized approach for EVs biochemical and physical characterization is still challenging due to this huge heterogeneity concerning origin, cargo and function. Up to now, no single technology has been reported to be highly efficient to fully cover the wide spectrum of EV properties and the use of combined complementary approaches to analyze EVs is recommended. $\mathrm{EV}$ analytical and detection techniques are based on multiple parameters, such as size and morphology, refractive index, or presence of a certain EV-specific marker. The most popular approaches for vesicle size distribution and concentration measurements include nanoparticle tracking analysis (NTA), dynamic light scattering (DLS), and tunable resistive pulse sensing (TRPS). Flow Cytometry is also a widely use method for characterization and quantification of EVs, and even more, the high-resolution flow cytometry is reported to be a proficient tool in $\mathrm{EV}$ analysis, providing increased sensitivity for the detection of smaller EVs $(<100 \mathrm{~nm})$. In addition, non-optical methods such as immunoaffinity-based EV techniques and western blot assays have also been employed for analysis of EVs. The physical and morphological characterization of EVs is mostly performed by direct imaging with atomic force microscopy (AFM), transmission electron microscopy (TEM) and, more recently, cryo-TEM. Moreover, novel integrated lab-on-a-chiptype microfluidic devices for the detection and analysis of EVs have been developed (Coumans et al., 2017; Szatanek et al., 2017; Chiriacò et al., 2018; van der Pol et al., 2018).

Notably, the International Society for Extracellular Vesicles (ISEV) has recently suggested the minimal information required for EV research, with detailed guidelines for how to best isolate and characterize the different types of EVs (Théry et al., 2018). Combined EV isolation methods as well as improved techniques for accurate characterization are strongly recommended, toward a review of their classification, composition and biological roles. An overview of different EV isolation and detection methods is reported in Table $\mathbf{1}$.

\section{Classification}

A conventional EV classification is based on their biogenesis and biophysical characteristics and distinguishes EVs into three major populations: exosomes, microvesicles (MVs), and apoptotic bodies. However, this classification should be considered with caution in line with recent evidences that report the presence of other subsets of EVs and add a new layer of complexity that need to be addressed in EV field (Figure 1).

Exosomes are small extracellular nano-size vesicles, typically $30-100 \mathrm{~nm}$ in diameter that are formed as intraluminal vesicles within endosomal multivesicular bodies (MVBs), and are released from cells upon the fusion of MVBs with the plasma membrane (Raposo and Stoorvogel, 2013). MVBs can also fuse with lysosomes to degrade the content. The outward budding of exosomal membranes can be regulated by the endosomal sorting complex required for transport (ESCRT) proteins or by neutral sphingomyelinase and ceramide in an ESCRT-independent manner (Stuffers et al., 2009). Due to their endocytic origin, exosomes can be identified by specific markers such as proteins involved in MVB biogenesis (ALIX and TSG101), membrane transport and fusion proteins (GTPases, Annexins, and flotillin) and tetraspanin proteins (CD9, CD63, CD81) (Mathivanan and Simpson, 2009). Exosomal membranes are enriched in elements of lipid rafts (e.g., GM1 gangliosides) and lipid components 
TABLE 1 | Isolation and detection methods of different EV subtypes.

\begin{tabular}{|c|c|c|c|c|}
\hline EV subtypes & Size range & Biogenesis & Isolation & Detection \\
\hline $\begin{array}{l}\text { Exosomes (Exo) } \\
\text { (Théry et al., 2006, } \\
\text { 2018; Raposo and } \\
\text { Stoorvogel, 2013; } \\
\text { Yáñez et al., 2015; } \\
\text { Kowal et al., 2016; } \\
\text { Willms et al., 2018; } \\
\text { Jeppesen et al., } \\
\text { 2019) }\end{array}$ & $30-100 \mathrm{~nm}$ & $\begin{array}{l}\text { Release by exocytosis } \\
\text { of multivesicular bodies } \\
\text { (MVBs) }\end{array}$ & $\begin{array}{l}\text { Differential centrifugation and } \\
\text { density gradients } \\
(100,000-200,000 \times g) \text {, } \\
\text { immunoprecipitation, } \\
\text { commercial kit, size exclusion } \\
\text { chromatography }\end{array}$ & $\begin{array}{l}\text { TEM, AFM, NTA, TRPS, } \\
\text { DLS, WB, flow cytometry } \\
\text { (bead coupled), ELISA }\end{array}$ \\
\hline $\begin{array}{l}\text { Microvesicles } \\
\text { (MVs) (Lötvall et al., } \\
\text { 2014; Cocucci and } \\
\text { Meldolesi, 2015; } \\
\text { Kowal et al., 2016; } \\
\text { Szatanek et al., } \\
\text { 2017; Chiriacò et al., } \\
\text { 2018; Crescitelli } \\
\text { et al., 2020) }\end{array}$ & $100-1,000 \mathrm{~nm}$ & $\begin{array}{l}\text { Direct budding of the } \\
\text { cell membrane }\end{array}$ & $\begin{array}{l}\text { Differential centrifugation } \\
(10,000-20,000 \times g) \\
\text { Density gradients }\end{array}$ & $\begin{array}{l}\text { TEM, AFM, WB, flow } \\
\text { cytometry (for vesicles } \\
>300 \mathrm{~nm} \text { ) }\end{array}$ \\
\hline $\begin{array}{l}\text { Apoptotic bodies } \\
\text { (Wickman et al., } \\
\text { 2012; Atkin-Smith } \\
\text { et al., 2015; Xu } \\
\text { et al., 2019) }\end{array}$ & $500-5 \mu \mathrm{m}$ & $\begin{array}{l}\text { Outward blebbing and } \\
\text { fragmentation of the } \\
\text { cell membrane }\end{array}$ & Centrifugation, filtration & TEM, IF, flow cytometry \\
\hline
\end{tabular}

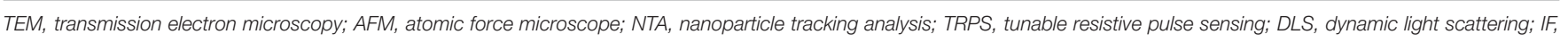
immunofluorescence microscopy; ELISA, enzyme-linked immunosorbent assay; WB, western blotting.

including cholesterol, ceramide, and sphingomyelin (Yáñez et al., 2015).

MVs, also known as ectosomes or shedding vesicles (SVs), are larger than exosomes ranging in size typically from 100 to $1,000 \mathrm{~nm}$ in diameter (Cocucci and Meldolesi, 2015). They originate directly by the outward budding of the plasma membrane and are subsequently released into the extracellular space after a selective incorporation of proteins, nucleic acids and lipids (Tricarico et al., 2016). The outer leaflet of the MV membrane is enriched with phosphatidylserine and sphingomyelin but also cholesterol and transmembrane proteins, which enable MV shedding through charges in plasma membrane shape (Muralidharan-Chari et al., 2010). Common markers used for identifying exosomes, such as CD63 and CD81 tetraspanins or components of the endosomal complex, such as TSG101 and ALIX, can also be found in MVs. However, CD40 ligand, ADP-ribosylation factor 6 (ARF6), HSP90, gp96 and different protein associated to lipid rafts, such as integrins and flotillins, are reported as MV markers (Muralidharan-Chari et al., 2009; Kim et al., 2012; Lötvall et al., 2014). Recently, Annexin A1 has been proposed as a novel and specific marker for MVs (Jeppesen et al., 2019).

Apoptotic bodies are $500 \mathrm{~nm}-5 \mu \mathrm{m}$ in diameter and are released into the extracellular environment during the cell apoptotic process (Muhsin-Sharafaldine and McLellan, 2018; Xu et al., 2019). They contain fragmented subcellular organelles for degradation, and they can be characterized by cellular organelles and DNA (Caruso and Poon, 2018).
Due to the substantial size overlap among these membrane vesicles, confusion on their nomenclature has spread throughout the literature, limiting a consensus on understanding the specific biological functions of different categories of vesicles. Along with the definition of a uniformly accepted EVs nomenclature, further studies specifically addressing EVs subtypes are needed in order to better standardize results obtained in the field. For clarity, in this review, we will specify/discriminate exosomes and MVs exclusively in studies concerning MS allowing for this distinction and use the term EVs when both types of vesicles are investigated.

\section{EVs IN CNS AND NEUROINFLAMMATION}

\section{EVs in Neurological Diseases}

The CNS is a complex organ comprising several cell types, each exerting a unique function. Neurons, astrocytes (Thompson et al., 2016), oligodendrocytes (Frühbeis et al., 2012), and microglia (Verderio et al., 2012) have all been reported to release EVs in vitro and in vivo, contributing in physiological and pathological conditions in the brain. EVs are involved in transporting signals between neighboring cells within the CNS (Basso and Bonetto, 2016; van der Vos et al., 2016), and are implicated in other processes, including development, synaptic neurotransmission, neurodegeneration, and tumor progression.

Thanks to their biological characteristics, EVs spread around the CNS but can easily cross the BBB and diffuse into peripheral blood and reach other organs. Several mechanisms have been proposed, however it seems that exosomes can cross the BBB by moving from cell to cell via MVB compartment and endocytosis (Record et al., 2011). More recently, exosomes 


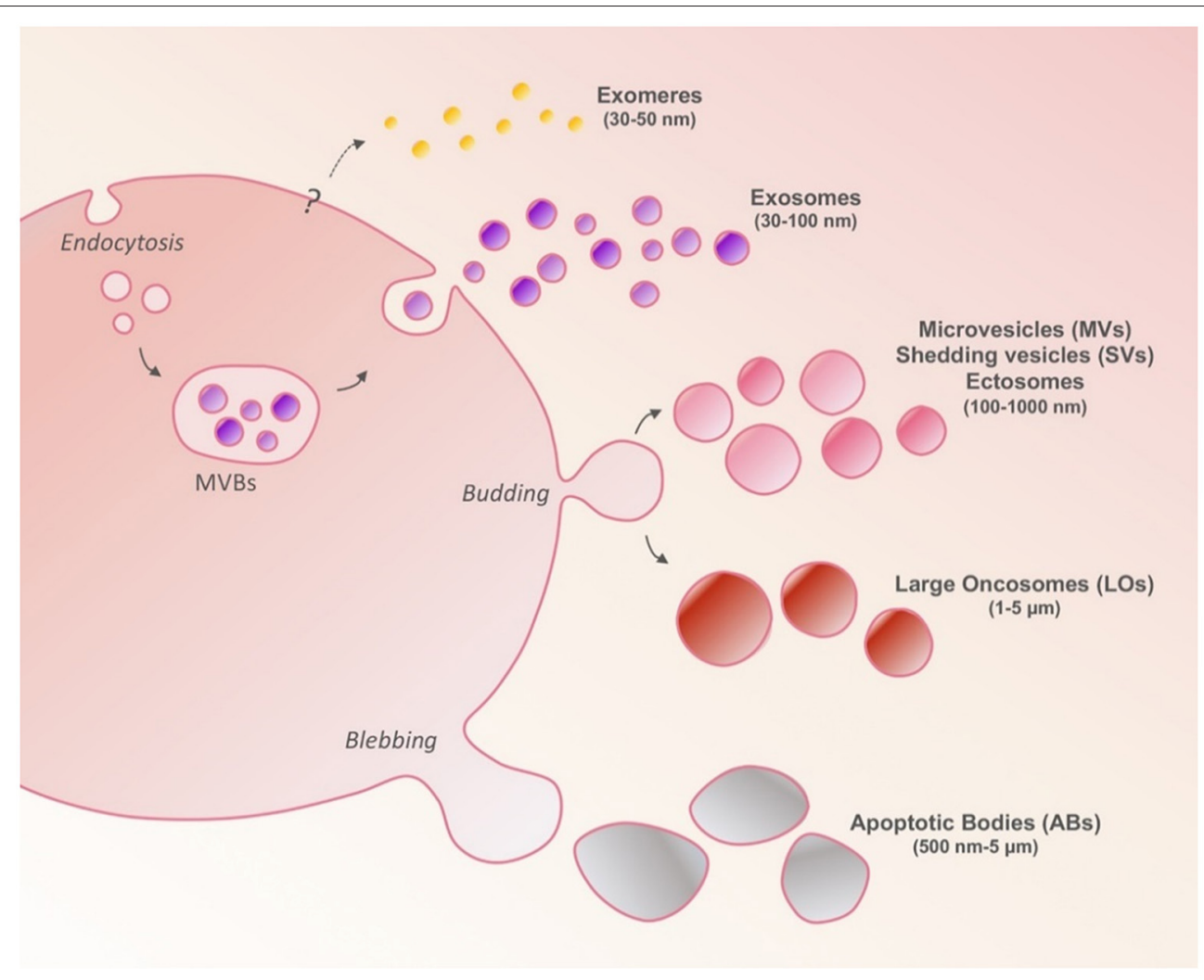

FIGURE 1 | Cells release heterogeneous populations of EVs different in sizes and secretion pathways. Exosomes are generated intracellularly from multivesicular bodies (MVBs). Microvesicles (MVs) are larger than exosomes and arise as a result of outward budding and fission of the plasma membrane. Large oncosomes (LOs) are derived from the shedding of non-apoptotic blebs unique to cancer cells. Apoptotic bodies are released upon cell fragmentation during apoptotic cell death. Exomeres have been recently suggested to be non-membranous nanoparticles with size smaller than $50 \mathrm{~nm}$; their biological role remains unknown.

released by a human glioma transplanted in mouse brain were detected in peripheral blood, crossing an intact BBB (García-Romero et al., 2017).

One notable example for the study of EVs spreading in the periphery, comes from the study of a mouse model of CNS injury. Exosomes isolated from peripheral blood of damaged brain mice where intravenously injected into naïve mice, causing an immune cell activation in the liver of recipient mice (Couch et al., 2017). This is the first study which strongly indicates an immune activation of cells in CNS disease mediated by exosomes.

According to the possibility for the EVs to cross both undamaged and disrupted $\mathrm{BBB}$, EVs could be detected in different biological fluids and represent a new class of biomarkers (Verderio et al., 2012; Galazka et al., 2017) and be also implicated in some stage of MS development and pathogenesis (Dolcetti et al., 2020).

\section{MS Pathogenesis}

MS is a chronic inflammatory autoimmune demyelinating disease of the CNS (Harbo et al., 2013). It affects worldwide more than 2 million people, being the most common immune mediated CNS disease. MS has a typical onset between the ages of 20-40 years, women outnumbering men 3:1, being for both sexes the leading cause of non-traumatic disability in young adults (Harbo et al., 2013).

Clinically heterogeneous, MS can be classified into different disease phenotypes. These include relapsing remitting MS (RRMS), secondary progressive MS (SPMS), primary progressive MS (PPMS), and clinically isolated syndrome (CIS) (Lublin et al., 2014). The most common form is RRMS, characterized by acute episodes of neurological deficit (relapses) followed by partial or complete clinical remission (Weiner, 2008). On the opposite, the progressive forms of MS are characterized by insidious disability accrual over time that can start ab initio (PPMS) or after a RR phase (SPMS). CIS is defined as the first clinical manifestation of a diseases that shows features of demyelination typical of MS, not fulfilling yet MS diagnostic criteria (Lublin et al., 2014). In addition, radiologically isolated syndrome (RIS) is characterized MRI incidental findings of CNS lesions suggestive of demyelination (Lebrun-Frenay et al., 2020). Inflammation, demyelination, gliosis and axonal degeneration are major histopathological hallmarks, responsible for different and unpredictable clinical courses (Ransohoff et al., 2015). Despite huge advances in its neurobiology, neuroimaging, neuropathology, MS remains a disease of unknown etiology. Epidemiological data suggest an etiological role for both 
genetic and environmental factors. Biological findings point to neuroinflammation and neurodegeneration as intertwined mechanisms involved in MS pathogenesis (Ransohoff et al., 2015). Crucial players of neuroinflammation are dysfunctional cells of both innate and adaptive immune system. Monocytes and peripherally activated $\mathrm{T}$ and $\mathrm{B}$ cells transmigrate from the blood to the CNS where they start myelin and axonal disruption (Lassmann, 2019). From peripheral activation to neural destruction, almost all pathogenetic steps have been largely studied and various mechanisms have been elucidated. A defective functioning of FoxP3-CD $4^{+} \mathrm{CD} 25^{\text {high }}$ regulatory $\mathrm{T}$ cells exosomes is recognized as contributing to an insufficient suppression, leading to a possible mechanism of activation of autoreactive $\mathrm{T}$ cells in periphery (Azimi et al., 2018). Upon activation these cells transmigrate across BBB by a multistep process where endothelial adhesion molecules and cognate ligand on leukocytes are involved (Brandstadter and Katz Sand, 2017).

The most convincing evidence of how crucial this step is, is provided by the effectiveness of natalizumab. This disease modifying drug interferes with an adhesion molecule (integrina4) leading to a robust decrease in clinical and radiological disease activity in most of the treated RRMS patients (Havrdova et al., 2009). Once in the CNS, these cells undergo further activation and together with microglia orchestrate myelin and axonal destruction (Lassmann, 2019). A proinflammatory environment caused by cytokines and chemokines, proteolytic enzymes and neurotoxic products leads to neuroinflammation, demyelination and neurodegeneration occurring through CNS white and gray matter.

Since a long time, neurodegeneration has been recognized as crucial pathogenetic mechanism in MS, already present in the early stages of disease. Among others, oxidative stress, iron accumulation, mitochondrial injury, ion channel dysfunction, glutamate excitossicity are widely found in MS neurodegeneration (Lassmann, 2019).

Unfortunately, when, how and to what extent these phenomena get into action is still elusive.

\section{EVs Role in MS}

In 2017 (Mustapic et al., 2017) L1 cell adhesion molecule (L1CAM) was appointed as a promising marker for EVs derived from CNS region. The possibility of identifying EVs of neural origin represent a precious messenger of tissue releasing them. Deciphering their origin and biogenesis can provide new insight into MS pathogenetic mechanisms still partially understood. Conflicting results about EVs role in MS can be ascribed to different methods of studies but also to a Janus role that EVs play in MS. Depending on cell of origin, microenvironment, status of disease, EVs can be detrimental or protective.

Studies in vitro have shown that endothelium-derived EVs are involved in the activation of $\mathrm{CD}^{+}$and $\mathrm{CD}^{+} \mathrm{T}$ lymphocytes (Wheway et al., 2014) and can cause their infiltration in the CNS.

One of the most accredited mechanisms postulate that EVs carrying metalloproteinases have a key role in BBB disruption (Sáenz-Cuesta et al., 2014). Again, recent studies demonstrated that EVs derived from brain microvascular endothelial cells can provide a bridge protein (claudin-5) between leukocytes and endothelial cells inducing transendothelial migration of the former (Paul et al., 2016).

An indirect confirmation of detrimental role of EVs in MS pathogenesis comes from experimental autoimmune encephalomyelitis (EAE), mouse model of MS. A-SMase KO mice, genetically impaired in MVs production, are protected from EAE (Verderio et al., 2012).

By contrast, several studies suggest a repairing activity of EVs. Indeed, microglia exposed to IL4 or mesenchymal stem cell (MSC) can release EVs promoting oligodendrocyte precursors cells (OPC) migration and/or differentiation. Lipids embedded in EV surface have being indicated as crucial mediators of this myelin repairing activity (Lombardi et al., 2019). Using EVs as therapeutic vector to mediate a protective and repairing activity during the disease will be further explored in the review.

Again, one of the first studies focusing on EVs (Scolding et al., 1989) reported that oligodendrocytes can recover from injury by "membrane-attack complex-enriched vesicles" released from the surface of viable cells.

A protective function of EVs was further studied in MS during pregnancy. It is known that MS female patients experience less severe symptoms and less frequent relapse during pregnancy (Airas and Kaaja, 2012). Studies in the animal model showed that serum derived EVs from mice in late pregnancy were more numerous than those isolated from virgin mice (Gatson et al., 2011). Moreover, $T$ cells co-cultured with exosomes from pregnant mice induced stronger suppression of T-cell proliferation compared to exosomes obtained from virgin animals (Gatson et al., 2011). A further study by the same group showed a reduction in IFN- gamma production and decreased expression of Tbet (Th1 transcription factor) in $\mathrm{T}$ cells exposed to pregnancy-derived exosomes. In addition, the authors demonstrated, in EAE, the positive effect of pregnancyderived exosomes on oligodendrocyte precursor cells migration to lesion areas and subsequent maturation (Williams et al., 2013). Accordingly, authors conclude that EVs are among crucial agents responsible for the immune modulation in pregnant EAE mice.

Besides "conventional" immune cells, myeloid cells, such as infiltrating macrophages and resident microglia, have been indicted in MS pathogenesis. Like EVs, their role is dual, acting either as harmful or as protective factor. Indeed, activated myeloid cells release EVs detectable in CSF of MS patients and animal models (Carandini et al., 2015; Nigro et al., 2016). For example, pro-inflammatory cytokines such as IL $1 \beta, \operatorname{IFN} \gamma$, $\mathrm{TNF} \alpha$, and caspase 1 can be loaded inside EVs and boost an inflammatory microenvironment. As previously mentioned, EVs contain metalloproteinases responsible for degradation of the extracellular matrix and tight junctions, facilitating leukocytes infiltration (Sáenz-Cuesta et al., 2014; Zappulli et al., 2016). Consequently, injection of microglia-derived EVs into EAE mice led to a recruitment of inflammatory T-cells and exacerbated the disease (Verderio et al., 2012; Sáenz-Cuesta et al., 2014).

Another source of EVs is represented by those released by astrocytes. In response to neuronal injury, astrocytes become activated and release EVs containing IL-1 $\beta$, which exacerbates tissue deterioration, fostering a vicious circle (Prada et al., 2018). 


\section{EVs IN MS CLINICAL PRACTICE EVs as Biomarkers}

Despite of a large research effort, several biomarkers have been proposed for MS, but their clinical relevance remains uncertain (Selmaj et al., 2017; Ziemssen et al., 2019). Complex diseases require biomarkers that allow to read into their complexity. In this direction, EVs seem to be good candidates. They are known to cross the $\mathrm{BBB}$, allowing CNS EVs to be detectable in peripheral fluids (Verderio et al., 2012; Galazka et al., 2017; Shi et al., 2019) and their unique content could give information about the origin cells and on the pathological process they are involved in. Considering this, interest in EVs as a potential biomarker in neuroinflammatory diseases is constantly increasing. The number of original researches dealing with EVs in MS has more than quadrupled in the last 5 years, compared to the same previous period.

We identified 27 original researches on the PubMed Database relating to EVs as biomarker in MS (see Table 2) published from 2011 to early 2020. Sixteen of these works analyzed plasma or serum-derived EVs, seven from CSF, six from the supernatant of cell cultures or PBMC, one from urine and one from tears. In nine papers the miRNA contained in the EVs was investigated. Seven papers were focused on differences in concentration of EVs with specific surface markers, while three studies investigated concentration or production of the total EVs population. Five publications analyzed EVs protein content, whereas two investigated lipid cargo. Finally, three papers were focused on functional assays.

To the date, none of the published works reached the ambitious target of a possible use of EVs in MS clinical practice. Papers focusing on CSF-EVs demonstrated good correlations with MS disease activity or disability (Verderio et al., 2012; Geraci et al., 2018; Pieragostino et al., 2018), in some cases supporting also a role in the diagnostic process (Verderio et al., 2012). Nevertheless, since CSF collection requires an invasive procedure, CSF-EVs don't meet the need of an easilycollectable biomarker (Ziemssen et al., 2019), preventing their use in monitoring disease over time. Serum/plasma-derived EV miRNAs were found to be possible markers of disease activity (Niwald et al., 2017; Selmaj et al., 2017; Ebrahimkhani et al., 2020), together with serum exosomal MOG protein (Galazka et al., 2017). EV miRNAs were also proposed as potential biomarkers of treatment response (Manna et al., 2018; Ebrahimkhani et al., 2020), as well as platelet-derived EVs (Nordberg et al., 2011), whereas lipid content correlates with disability (Moyano et al., 2016). Nonetheless, taking into account the complexity and cost of EV isolation and characterization, these findings do not provide yet an added value to clinical and MRI management of MS patients (Ziemssen et al., 2019). Interestingly, Ebrahimkhani et al. (2017) proposed miRNA signatures able to distinguish RRMS from PMS, addressing a dramatically open issue of this disease.

However, a common limit of all the studies about blood EVs is that they do not specifically address CNS-derived EVs. Recently, Goetzl et al. (2015) published a method to enrich plasma exosomes for neuronal origin. This method was then replicated and applied also for astrocyte-derived (Goetzl et al., 2016, 2018) and oligodendrocyte-derived exosomes (Dutta et al., 2018). Since CNS-derived exosomes represent a very small percentage of the total plasma/serum exosome population (Hornung et al., 2020), the employment of CNS-derived exosomes enriching techniques might lead to peripherally collectable CNS biomarkers in MS, as demonstrated in other neurological diseases (e.g., Alzheimer disease, brain traumatic injury) (Goetzl et al., 2015, 2019).

The wide variability in isolation methods and analysis (see Table 2) makes an organic interpretation of the published works at least challenging. According to comparison studies, different isolation methods have different performances concerning purity of samples and co-isolation of contaminating material (Baranyai et al., 2015; Lee et al., 2019; Takov et al., 2019). In light of this, Rekker et al. (2014) observed that exosomal miRNA profile is affected by the isolation method (i.e., Ultracentrifugation vs. ExoQuick). Tang et al. (2017) demonstrated similar results. The choice of different methods among authors [not always in agreement with those suggested by ISEV (Théry et al., 2018)] might affect the reliability and consistency of the findings, both for cargo analysis and functional assays (Takov et al., 2019). Finally, as discussed above, Jeppesen et al. (2019) had recently published an important paper that strongly stresses the need for exosome composition reassessment, changing the whole EVs research scenario. In this direction, a further validation of what previously published about EVs and MS should be required.

\section{EVs as Therapeutic Tool}

MS and its animal model EAE are the most common inflammatory demyelinating diseases caused by autoimmuneactivated immune cells in the CNS (Li et al., 2017; Zhang Y. et al., 2018). It has been reported that EVs can penetrate the $\mathrm{BBB}$ and contribute to brain antigens spreading to the periphery (Selmaj et al., 2017). The injection of microglia-derived EVs into the CNS of EAE mice enhanced inflammation and exaggerated disease (Verderio et al., 2012). Moreover, mice with an impaired ability to secrete EVs were resistant to EAE (Verderio et al., 2012). Accordingly, it's conceivable that EVs are involved in EAE pathogenesis.

Based on the possible role of EVs in EAE and MS, some groups developed treatment strategies that employed the use of EVs as therapeutic tool to treat neuroinflammation and demyelination.

The use of MSCs has always given good outcomes in the treatment of EAE and is currently in clinical trial for MS (Karussis et al., 2010; Yamout et al., 2010; Cohen, 2013). Nevertheless, cell-based therapies are affected by the immune rejection of donor cells among main safety issues (Kim and Park, 2017). To overcome this problem, several groups are now interested in eliminating the rejection problem by administering a non-cell based treatment, namely EVs. MSCs stimulated with IFN $\gamma$ produce exosomes carrying these cytokines, and their administration results in a good therapeutic effect on EAE (Riazifar et al., 2019). Again, MSCs derived from placenta were found effective in having a regenerative, immunomodulatory and protective effect. The exosomes derived from this type of cells can reduce DNA damage in oligodendroglia and increase myelination within the spinal cord of treated mice 
TABLE 2 | EVs as biomarkers in MS.

\begin{tabular}{|c|c|c|c|c|c|c|c|c|}
\hline References & Patients & EV & $\begin{array}{l}\text { Isolation } \\
\text { method }\end{array}$ & $\begin{array}{l}\text { Quantification } \\
\text { method }\end{array}$ & Source & Cargo/measures & Results & Biomarker \\
\hline Azimi et al. (2019 & RRMS, HC & Exo & $\begin{array}{l}\text { Total exosome } \\
\text { isolation kit } \\
\text { (Invitrogen) }\end{array}$ & Elisa & T cell cultures & miRNA & $\begin{array}{l}\text { miR-326 is upregulated in } \\
\text { RRMS vs. HC. }\end{array}$ & Diagnostic \\
\hline $\begin{array}{l}\text { Bhargava et al. } \\
\text { (2019) }\end{array}$ & RRMS, HC & Exo & \multicolumn{2}{|c|}{$\begin{array}{l}\text { Exoquick (SystemNTA-nanosight } \\
\text { Biosciences) }\end{array}$} & Serum & Concentration protein & $\begin{array}{l}\text { TLR3 reduction, TLR4 } \\
\text { increase in RRMS vs. HC. }\end{array}$ & Diagnostic \\
\hline $\begin{array}{l}\text { Pieragostino et al } \\
\text { (2019) }\end{array}$ & I.MS, HC & EVs & FACS & $\begin{array}{l}\text { FACS, } \\
\text { Dynamic } \\
\text { light scattering }\end{array}$ & CSF, Tears & Proteomics & $\begin{array}{l}\text { Microglial and neuronal EVs } \\
\text { detectable in CSF and tears. } \\
\text { Protein cargo is different } \\
\text { between MS and HC. } \\
\text { Protein cargo overlap (70\%) } \\
\text { between tears and CSF EV } \\
\text { in MS. }\end{array}$ & Diagnostic \\
\hline $\begin{array}{l}\text { Amoruso et al. } \\
\text { (2018) }\end{array}$ & RRMS, HC & MV & $\begin{array}{l}\text { Differential } \\
\text { centrifugation }\end{array}$ & Fluorescence & Monocytes & Concentration & $\begin{array}{l}\text { Increased MVs concentration } \\
\text { in RRMS vs. HC, reduced by } \\
\text { FTY }\end{array}$ & $\begin{array}{l}\text { Diagnostic, } \\
\text { treatment effect }\end{array}$ \\
\hline Azimi et al. (2018 & RRMS, HC & Exo & $\begin{array}{l}\text { Total exosome } \\
\text { isolation kit } \\
\text { (Invitrogen) }\end{array}$ & Elisa & Treg cultures & Functional assay & $\begin{array}{l}\text { Treg-derived MS exo are less } \\
\text { effective in suppressing } \\
\text { conventional T cell } \\
\text { proliferation and in inducing T } \\
\text { cell apoptosis. }\end{array}$ & Diagnostic \\
\hline $\begin{array}{l}\text { Geraci et al. } \\
(2018)\end{array}$ & RRMS, OND & EV & $\begin{array}{l}\text { Differential } \\
\text { centrifugation }\end{array}$ & $\begin{array}{l}\text { FACS, } \\
\text { NTA-nanosight }\end{array}$ & CSF & $\begin{array}{l}\text { Concentration } \\
\text { Markers }\end{array}$ & $\begin{array}{l}\text { No differences in } \\
\text { concentration and Ib4 } \\
\text { positivity in MS vs. OND. } \\
\text { Increased concentration, Ib4 } \\
\text { positivity and CD } 19^{+} / \mathrm{CD} 200^{+} \\
\text {in active vs. stable MS. } \\
\mathrm{CCR} 3^{+} \mathrm{CCR} 5^{+} \\
\mathrm{CD} 4^{+} / \mathrm{CCR} 3^{+}, \mathrm{CD} 4^{+} / \mathrm{CCR} 5^{+} \\
\mathrm{CC}^{+} / \mathrm{CCR} 5^{+} \text {are increased } \\
\text { in } \mathrm{MS} \text { with MRI activity. }\end{array}$ & $\begin{array}{l}\text { Disease activity } \\
+ \\
+ \\
+\end{array}$ \\
\hline $\begin{array}{l}\text { Manna et al. } \\
(2018)\end{array}$ & RRMS & Exo & $\begin{array}{l}\text { Exoquick } \\
\text { (System } \\
\text { Biosciences) }\end{array}$ & $\begin{array}{l}\text { Dynamic light } \\
\text { scattering }\end{array}$ & Serum & miRNA & $\begin{array}{l}\text { miRNA differential expression } \\
\text { between IFNB-treated vs. } \\
\text { naive RRMS. miRNA } \\
\text { differential between IFN } \\
\text { responders vs. } \\
\text { non-responders }\end{array}$ & $\begin{array}{l}\text { Treatment effect, } \\
\text { Response to } \\
\text { treatment }\end{array}$ \\
\hline $\begin{array}{l}\text { Pieragostino et al } \\
\text { (2018) }\end{array}$ & $\begin{array}{l}\text { I.MS, } \\
\text { c-OND, } \\
\text { p-OND }\end{array}$ & Exo & FACS & $\begin{array}{l}\text { FACS, Dynamic } \\
\text { light scattering }\end{array}$ & CSF & Lipids & $\begin{array}{l}\text { Increased Exo concentration } \\
\text { in MS vs. to p-and c-OND. } \\
\text { Concentration correlates with } \\
\text { acid sphingomyelinase } \\
\text { activity. } \\
\text { Exo deliver active acid } \\
\text { sphingomyelinase cargo. } \\
\text { Exosomal acid } \\
\text { sphingomyelinase activity } \\
\text { correlates with EDSS. }\end{array}$ & $\begin{array}{l}\text { Diagnostic, } \\
\text { Disability }\end{array}$ \\
\hline
\end{tabular}


TABLE 2 | Continued

\begin{tabular}{|c|c|c|c|c|c|c|c|c|}
\hline References & Patients & EV & $\begin{array}{l}\text { Isolation } \\
\text { method }\end{array}$ & $\begin{array}{l}\text { Quantification } \\
\text { method }\end{array}$ & Source & Cargo/measures & Results & Biomarker \\
\hline $\begin{array}{l}\text { Sáenz-Cuesta } \\
\text { et al. (2018) }\end{array}$ & RRMS, HC & EVs & $\begin{array}{l}\text { Differential } \\
\text { centrifugation }\end{array}$ & NTA-nanosight & Serum & $\begin{array}{l}\text { Concentration miRNA } \\
\text { Functional assays }\end{array}$ & $\begin{array}{l}\text { FTY increases EVs } \\
\text { concentration. } \\
\text { FTY changes EVs miRNA } \\
\text { expression. } \\
\text { FTY reduces the ability of EVs } \\
\text { to inhibit } \\
\text { lymphocyte activation. }\end{array}$ & Treatment effect \\
\hline $\begin{array}{l}\text { Blonda et al. } \\
\text { (2017) }\end{array}$ & RRMS, HC & MV & $\begin{array}{l}\text { Differential } \\
\text { centrifugation }\end{array}$ & Fluorescence & Monocytes & Production & $\begin{array}{l}\text { Increased MVs concentration } \\
\text { in MS. IFNB, TFM, and FTY } \\
\text { reduce monocyte MVs } \\
\text { production. }\end{array}$ & $\begin{array}{l}\text { Disease, } \\
\text { Treatment effect }\end{array}$ \\
\hline $\begin{array}{l}\text { Dalla Costa et al. } \\
\text { (2018) }\end{array}$ & RRMS, HC & MV & $\begin{array}{l}\text { Differential } \\
\text { centrifugation }\end{array}$ & FACS & Monocytes & Concentration & $\begin{array}{l}\text { Increased MV concentration } \\
\text { in RRMS vs. HC. } \\
\text { FTY reduces concentration, } \\
\text { NTZ increases it. No } \\
\text { differences for IFN and GA. }\end{array}$ & $\begin{array}{l}\text { Diagnostic, } \\
\text { Treatment effect }\end{array}$ \\
\hline $\begin{array}{l}\text { Galazka et al. } \\
\text { (2017) }\end{array}$ & $\begin{array}{l}\text { MS (RR, PMS), } \\
\mathrm{HC}\end{array}$ & Exo & $\begin{array}{l}\text { Exoquick kit } \\
\text { (System } \\
\text { Biosciences) }\end{array}$ & NTA-nanosight & Serum, CSF & Concentration protein, & $\begin{array}{l}\text { MOG is increased in RRMS } \\
\text { and SPMS. } \\
\text { MOG correlates with MRI } \\
\text { activity. } \\
\text { MS exo induces proliferation } \\
\text { of MOG-TCR transgenic } \\
\text { T cells. }\end{array}$ & $\begin{array}{l}\text { Diagnostic, } \\
\text { Disease activity }\end{array}$ \\
\hline $\begin{array}{l}\text { Welton et al. } \\
\text { (2017) }\end{array}$ & RRMS vs. IIH & Exo & Exo-spin (Cell GS) & ) NTA-nanosight & CSF & $\begin{array}{l}\text { Concentration } \\
\text { proteomics }\end{array}$ & $\begin{array}{l}\text { Higher concentration and } p / p \\
\text { ratio in RRMS. } \\
50 \text { proteins specifically } \\
\text { enriched in RRMS exo vs. } \\
\text { RRMS CSF. }\end{array}$ & Diagnostic, \\
\hline Lee et al. (2019) & $\begin{array}{l}\text { MS, NMO, } \\
\text { LETM }\end{array}$ & Exo & $\begin{array}{l}\text { Differential } \\
\text { centrifugation }\end{array}$ & $\begin{array}{l}\text { FACS, } \\
\text { NTA-nanosight }\end{array}$ & CSF & Proteomics & $\begin{array}{l}\text { MS and NMO have a different } \\
\text { exosomal protein content. }\end{array}$ & Diagnosis \\
\hline $\begin{array}{l}\text { Moyano et al. } \\
\text { (2016) }\end{array}$ & RRMS, HC & Exo, MV & $\begin{array}{l}\text { Differential } \\
\text { centrifugation }\end{array}$ & NTA-nanosight & Plasma & $\begin{array}{l}\text { Concentration size } \\
\text { lipids }\end{array}$ & $\begin{array}{l}\text { C16:0 sulfatide is more } \\
\text { expressed in RRMS vs. HC. } \\
\text { Negative correlation } \\
\text { with EDSS. }\end{array}$ & $\begin{array}{l}\text { Diagnostic, } \\
\text { Disability }\end{array}$ \\
\hline $\begin{array}{l}\text { Zinger et al. } \\
(2016)\end{array}$ & RRMS, HC & EV & $\begin{array}{l}\text { Differential } \\
\text { centrifugation }\end{array}$ & FACS & Plasma & $\begin{array}{l}\text { Concentration } \\
\text { markers }\end{array}$ & $\begin{array}{l}\text { Total EV and } \mathrm{CD} 105^{+} \mathrm{MPs} \\
\text { are increased while CD19 } \\
\text { EV are reduced in untreated } \\
\text { RRMS vs. HC. } \\
\text { FTY restores their levels } \\
\text { comparable to HC. }\end{array}$ & $\begin{array}{l}\text { Diagnostic, } \\
\text { Treatment effect }\end{array}$ \\
\hline
\end{tabular}


TABLE 2 | Continued

\begin{tabular}{|c|c|c|c|c|c|c|c|c|}
\hline References & Patients & EV & $\begin{array}{l}\text { Isolation } \\
\text { method }\end{array}$ & $\begin{array}{l}\text { Quantification } \\
\text { method }\end{array}$ & Source & Cargo/measures & Results & Biomarker \\
\hline $\begin{array}{l}\text { Alexander et al. } \\
\text { (2015) }\end{array}$ & $\begin{array}{l}\text { MS (RR, SP), } \\
\mathrm{HC}\end{array}$ & Exo & $\begin{array}{l}\text { Differential } \\
\text { centrifugation }\end{array}$ & FACS & Plasma & $\begin{array}{l}\text { Concentration } \\
\text { markers }\end{array}$ & $\begin{array}{l}\text { Exo from different sources are } \\
\text { differently modulated in RR } \\
\text { and SPMS. Correlation with } \\
\text { MRI measures. }\end{array}$ & \\
\hline $\begin{array}{l}\text { Giovannelli et al. } \\
\text { (2015) }\end{array}$ & RRMS, HC & Exo & $\begin{array}{l}\text { Exosome-specific l } \\
\text { extraction kit } \\
\text { (Norgen) }\end{array}$ & cNone & Plasma, urine & miRNA & $\begin{array}{l}\text { JCV miRNA are more } \\
\text { represented in exo of JCV + } \\
\text { RRMS (NTZ) and HC. }\end{array}$ & $\begin{array}{l}\text { Treatment side } \\
\text { effects }\end{array}$ \\
\hline $\begin{array}{l}\text { Marcos-Ramiro } \\
\text { et al. (2014) }\end{array}$ & $\begin{array}{l}\text { MS (CIS, RR, } \\
\text { PMS), HC }\end{array}$ & EV & $\begin{array}{l}\text { Differential } \\
\text { centrifugation }\end{array}$ & FACS & Plasma & $\begin{array}{l}\text { Concentration } \\
\text { markers }\end{array}$ & $\begin{array}{l}\mathrm{CD}^{+} 2^{+} \text {and } \mathrm{CD} 31^{+} \text {are } \\
\text { increased in all MS subtypes } \\
\text { vs. } \mathrm{HC}\end{array}$ & Diagnostic \\
\hline $\begin{array}{l}\text { Sáenz-Cuesta } \\
\text { et al. (2014) }\end{array}$ & $\begin{array}{l}\text { RRMS, SPMS, } \\
\text { HC }\end{array}$ & MV & $\begin{array}{l}\text { Differential } \\
\text { centrifugation }\end{array}$ & FACS & Plasma & $\begin{array}{l}\text { Concentration } \\
\text { markers }\end{array}$ & $\begin{array}{l}\mathrm{CD} 1^{+}, \mathrm{CD}^{+} 5^{+}, \mathrm{CD} 14^{+} \mathrm{MP} \\
\text { are increased in RRMS vs. } \\
\text { SPMS and HC. NTZ and IFNB } \\
\text { treatment increase their level. }\end{array}$ & $\begin{array}{l}\text { Diagnostic, } \\
\text { treatment effect } \\
3\end{array}$ \\
\hline $\begin{array}{l}\text { Verderio et al. } \\
(2012)\end{array}$ & $\begin{array}{l}\text { MS, NMO, } \\
\text { OIND, ONIND, } \\
\text { HC }\end{array}$ & MV & FACS & FACS & CSF & $\begin{array}{l}\text { Concentration of } \\
\text { myeloid MVs }\end{array}$ & $\begin{array}{l}\text { Myeloid MVs are increased in } \\
\text { active RRMS compared to } \\
\text { stable RRMS and in CIS } \\
\text { compared to HC. MVs } \\
\text { concentration correlates with } \\
\text { MRI activity. }\end{array}$ & $\begin{array}{l}\text { Diagnostic } \\
\text { disease activity }\end{array}$ \\
\hline $\begin{array}{l}\text { Nordberg et al. } \\
\text { (2011) }\end{array}$ & MS & EV & FACS & FACS & Plasma & $\begin{array}{l}\text { Concentration } \\
\text { markers }\end{array}$ & $\begin{array}{l}\mathrm{CD} 31^{+} \text {and } \mathrm{CD} 54^{+} \mathrm{MPs} \text { are } \\
\text { reduced by IFNB. } \\
\text { Correlation with a reduction of } \\
\text { MRI activity. }\end{array}$ & $\begin{array}{l}\text { Response to } \\
\text { treatment } \\
\text { f }\end{array}$ \\
\hline
\end{tabular}

MS, multiple sclerosis; RR, relapsing remitting; PMS, progressive multiple sclerosis; SP, secondary progressive; HC, healthy controls; OND, other neurological disorders; IIH, idiopathic

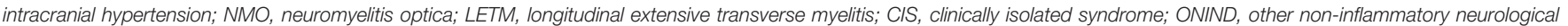

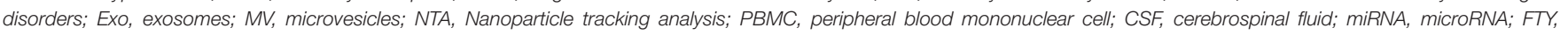
fingolimod; IFNB, interferon-beta; TFM, teriflunomide; NTZ, natalizumab; EDSS, expanded disability status scale; MOG, myelin oligodendrocyte glycoprotein.

(Clark et al., 2019). Conversely, bone marrow derived MSCs exosomes, administered systemically, can decrease the immune cell infiltration and inflammation in the CNS, together with decreasing the demyelinating process (Zhang Q. et al., 2018). In the same way, another group, using bone marrow derived MSCs pre-treated with IFN $\gamma$ has shown a decreased demyelination in EAE mice and manage to demonstrate that the administration of exosomes can ameliorate EAE by suppressing pathological Tcells activation and inducing Tregs action (Riazifar et al., 2019). Moreover, these exosomes seems to mediate a phenotype switch of microglia from a pro-inflammatory to a rescue phenotype ( $\mathrm{Li}$ et al., 2019). These data provided evidence that MSCs-derived exosomes can be used as cell-free therapies for autoimmune and central nervous system diseases.

In order to elicit a specific reaction, scientists use different cell source of EVs to hit specific target cells.

Accordingly, the use of EVs derived from dendritic cells overexpressing TGF- $\beta 1$ resulted in the inhibition of Th1 and Th17 differentiation and $\mathrm{T}$ reg cells were promoted, leading to milder EAE (Yu et al., 2013). Casella et al. designed a mouse microglial cell line releasing a large amount of engineered EVs containing the anti-inflammatory cytokine IL4 and expressing a target eat-me signal for macrophages on the surface. EAE mice injected with these engineered EVs show a less severe course of disease (Casella et al., 2018). Through intranasal route, Zhuang et al. (2011) manage to deliver curcumin-loaded exosomes in CNS and manage to reduce neuroinflammation by targeting resident microglia. Other than microglia, oligodendrocytes and their differentiation are an interesting target in treating demyelination in EAE. Pusic et al. (2014) used exosomes from bone marrow dendritic cells to support oligodendrocytes maturation. Exosomes produced by IFN $\gamma$ stimulated dendritic cells contain high levels of miR-219, a key player in oligodendrocyte precursors cells differentiation. In addition, these exosomes can increase the number of mature oligodendrocytes and help the remyelination process in vivo.

Compared to the crucial contribution and successful results of EVs in cancer treatment, EVs applications as therapeutic delivery vehicle in neuroinflammatory diseases are yet in their early stages (Villa et al., 2019; Hernandez-Oller et al., 2020; Li et al., 2020). Currently just one clinical trial is ongoing for the treatment of chronic postsurgical temporal bone inflammations (Clinicaltrials.gov, NCT04281901), but we are sure that in the next few years the number of clinical trials using EVs as therapeutic vector will increase.

\section{CONCLUSIONS}

There is increasing evidence, as described in this review, supporting a pivotal role for EVs both in CNS physiology and during neuroinflammatory pathogenetic processes. Most of our 
knowledge on the role of EVs in the CNS comes, however, from in vitro studies, since technologies to follow EVs fate in vivo are difficult and, in any case, uncertain. The development of tools allowing the modulation of CNS EVs release and/or uptake in vivo in animal models would represent a ground-breaking advancement for the field. This would allow to highlight EVs role in physiological and pathological processes, in vivo and possibly in a cell-specific manner. Unfortunately, available genetic models lack specificity and most pathways (and therefore genes) involved in EVs release or uptake have yet to be elucidated. Specific pharmacological tools, on the other hand, are also missing.

The use of EVs as biomarkers in clinical practice seems a more realistic short-term goal. As demonstrated by many studies, EVs can mirror the biology and environment of the donor cell, providing a broader information on ongoing pathologies in neurological patients. Both their number and content, comprising different kind of signals, may provide indication of disease stage and prognosis. Access to pathologically relevant tissues is extremely difficult for neurological diseases, thus the use of EVs may be key since may be easily isolated from the blood. What we still miss here is a deeper knowledge of EVs subpopulations in the blood, to differentiate and better characterize EVs origin and their content in physiological or pathological conditions. The uncertain and evolving technological landscape for EVs examination calls for a consensus on protocols, for standardization of EVs isolation

\section{REFERENCES}

Airas, L., and Kaaja, R. (2012). Pregnancy and multiple sclerosis. Obstet. Med. 5, 94-97. doi: 10.1258/om.2012.110014

Alexander, J. S., Chervenak, R., Weinstock-Guttman, B., Tsunoda, I., Ramanathan, M., Martinez, N., et al. (2015). Blood circulating microparticle species in relapsing-remitting and secondary progressive multiple sclerosis. A case-control, cross sectional study with conventional MRI and advanced iron content imaging outcomes. J. Neurol. Sci. 355, 84-89. doi: 10.1016/j.jns.2015.05.027

Amoruso, A., Blonda, M., D’Arrigo, G., Grasso, R., Di Francescantonio, V., Verderio, C., et al. (2018). Effect of fingolimod action on the release of monocyte-derived microvesicles in multiple sclerosis patients. $J$. Neuroimmunol. 323, 43-48. doi: 10.1016/j.jneuroim.2018.07.008

Atkin-Smith, G. K., Tixeira, R., Paone, S., Mathivanan, S., Collins, C., Liem, M., et al. (2015). A novel mechanism of generating extracellular vesicles during apoptosis via a beads-on-a-string membrane structure. Nat. Commun. 6:7439. doi: $10.1038 /$ ncomms8439

Azimi, M., Ghabaee, M., Moghadasi, A. N., Noorbakhsh, F., and Izad, M. (2018). Immunomodulatory function of Treg-derived exosomes is impaired in patients with relapsing-remitting multiple sclerosis. Immunol. Res. 66, 513-520. doi: 10.1007/s12026-018-9008-5

Azimi, M., Ghabaee, M., Naser Moghadasi, A., and Izad, M. (2019). Altered expression of miR-326 in T cell-derived exosomes of patients with relapsingremitting multiple sclerosis. Iran. J. Allergy Asthma Immunol. 18, 108-113. doi: 10.18502/ijaai.v18i1.636

Baranyai, T., Herczeg, K., Onódi, Z., Voszka, I., Módos, K., Marton, N., et al. (2015). Isolation of exosomes from blood plasma: qualitative and quantitative comparison of ultracentrifugation and size exclusion chromatography methods. PLoS ONE 10:e0145686 doi: 10.1371/journal.pone.0145686

Basso, M., and Bonetto, V. (2016). extracellular vesicles and a novel form of communication in the brain. Front. Neurosci. 10:127. doi: $10.3389 /$ fnins. 2016.00127 and analysis. International associations (i.e., ISEV) are trying to do this work but cannot avoid the publication of studies of heterogeneous quality.

Finally, the use of EVs as therapeutic vectors in neurological diseases is just at its beginning. There are some encouraging data and publications but many more pre-clinical studies must be performed before establishing ways of administration, nature of plausible cargos, in vivo fate, possible target cells, etc. The study of the therapeutic use of EVs in the cancer field is more advanced and raises hopes we might develop EVs as therapeutic vectors in clinical trials in the future also for neurological disorders.

There are still several technical challenges and even more learning needs on EVs biology, but we are convinced that current difficulties in this research field may be overcome, and that EVs may become in the next years not only clinically useful biomarkers, but also a source of information on disease pathogenesis and possibly an alternative therapy for currently untreatable diseases.

\section{AUTHOR CONTRIBUTIONS}

GM, SG, MG, and AN wrote the review and correct the text. RF supervised the writing of the review and correct the final form of the article. All authors contributed to the article and approved the submitted version.

Bhargava, P., Nogueras-Ortiz, C., Chawla, S., Bæk, R., Jørgensen, M. M., and Kapogiannis, D. (2019). Altered levels of toll-like receptors in circulating extracellular vesicles in multiple sclerosis. Cells 8:1058. doi: $10.3390 /$ cells 8091058

Blonda, M., Amoruso, A., Grasso, R., Di Francescantonio, V., and Avolio, C. (2017). Multiple sclerosis treatments affect monocyte-derived microvesicle production. Front. Neurol. 8:422. doi: 10.3389/fneur.2017.00422

Brandstadter, R., and Katz Sand, I. (2017). The use of natalizumab for multiple sclerosis. Neuropsychiatr. Dis. Treat. 13, 1691-1702. doi: 10.2147/NDT.S114636

Camussi, G., Deregibus, M. C., Bruno, S., Cantaluppi, V., and Biancone, L. (2010). Exosomes/microvesicles as a mechanism of cell-to-cell communication. Kidney Int. 78, 838-848. doi: 10.1038/ki.2010.278

Carandini, T., Colombo, F., Finardi, A., Casella, G., Garzetti, L., Verderio, C., et al. (2015). Microvesicles: what is the role in multiple sclerosis? Front. Neurol. 6:111. doi: 10.3389/fneur.2015.00111

Caruso, S., and Poon, I. K. H. (2018). Apoptotic cell-derived extracellular vesicles: more than just debris. Front. Immunol. 9:1486. doi: 10.3389/fimmu.2018.01486

Casella, G., Colombo, F., Finardi, A., Descamps, H., Ill-Raga, G., Spinelli, A., et al. (2018). Extracellular vesicles containing IL-4 modulate neuroinflammation in a mouse model of multiple sclerosis. Mol. Ther. 26, 2107-2118. doi: 10.1016/j.ymthe.2018.06.024

Chargaff, E., and West, R. (1946). The biological significance of the thromboplastic protein of blood. J. Biol. Chem. 166, 189-197.

Chiriacò, M. S., Bianco, M., Nigro, A., Primiceri, E., Ferrara, F., Romano, A., et al. (2018). Lab-on-chip for exosomes and microvesicles detection and characterization. Sensors 18:3175. doi: 10.3390/s18103175

Clark, K., Zhang, S., Barthe, S., Kumar, P., Pivetti, C., Kreutzberg, N., et al. (2019). Placental mesenchymal stem cell-derived extracellular vesicles promote myelin regeneration in an animal model of multiple sclerosis. Cells 8:1497. doi: $10.3390 /$ cells8121497

Cocucci, E., and Meldolesi, J. (2015). Ectosomes and exosomes: shedding the confusion between extracellular vesicles. Trends Cell Biol. 25, 364-372. doi: $10.1016 /$ j.tcb.2015.01.004 
Cohen, J. A. (2013). Mesenchymal stem cell transplantation in multiple sclerosis. J. Neurol. Sci. 333, 43-49. doi: 10.1016/j.jns.2012.12.009

Colombo, M., Raposo, G., and Théry, C. (2014). Biogenesis, secretion, and intercellular interactions of exosomes and other extracellular vesicles. Annu. Rev. Cell Dev. Biol. 30, 255-289. doi: 10.1146/annurev-cellbio-101512-122326

Couch, Y., Akbar, N., Roodselaar, J., Evans, M. C., Gardiner, C., Sargent, I., et al. (2017). Circulating endothelial cell-derived extracellular vesicles mediate the acute phase response and sickness behaviour associated with CNS inflammation. Sci. Rep. 7, 1-12. doi: 10.1038/s41598-017-09710-3

Coumans, F. A. W., Brisson, A. R., Buzas, E. I., Dignat-George, F., Drees, E. E. E., El-Andaloussi, S., et al. (2017). Methodological guidelines to study extracellular vesicles. Circ. Res. 120, 1632-1648. doi: 10.1161/CIRCRESAHA.117.309417

Crescitelli, R., Lässer, C., Jang, S. C., Cvjetkovic, A., Malmhäll, C., Karimi, N., et al. (2020). Subpopulations of extracellular vesicles from human metastatic melanoma tissue identified by quantitative proteomics after optimized isolation. J. Extracell. Vesicles 9:1722433. doi: 10.1080/20013078.2020.1722433

Crescitelli, R., Lässer, C., Szabó, T. G., Kittel, A., Eldh, M., Dianzani, I., et al. (2013). Distinct RNA profiles in subpopulations of extracellular vesicles: apoptotic bodies, microvesicles and exosomes. J. Extracell. Vesicles 2. doi: 10.3402/jev.v2i0.20677

Dalla Costa, G., Finardi, A., Garzetti, L., Carandini, T., Comi, G., Martinelli, V., et al. (2018). Disease-modifying treatments modulate myeloid cells in multiple sclerosis patients. Neurol. Sci. Off. J. Ital. Neurol. Soc. Ital. Soc. Clin. Neurophysiol. 39, 373-376. doi: 10.1007/s10072-017-3176-2

Dolcetti, E., Bruno, A., Guadalupi, L., Rizzo, F. R., Musella, A., Gentile, A., et al. (2020). Emerging role of extracellular vesicles in the pathophysiology of multiple sclerosis. Int. J. Mol. Sci. 21:7336. doi: 10.3390/ijms21197336

Dutta, S., del Rosario, I., Paul, K., Palma, J. A., Perlman, S. L., Poon, W. W., et al. (2018). $\alpha$-Synuclein in brain-derived blood exosomes distinguishes multiple system atrophy from Parkinson's disease. Ann. Neurol. 84, S191-S191.

Ebrahimkhani, S., Beadnall, H. N., Wang, C., Suter, C. M., Barnett, M. H., Buckland, M. E., et al. (2020). Serum exosome MicroRNAs predict multiple sclerosis disease activity after fingolimod treatment. Mol. Neurobiol. 57, 1245-1258. doi: 10.1007/s12035-019-01792-6

Ebrahimkhani, S., Vafaee, F., Young, P. E., Hur, S. S. J., Hawke, S., Devenney, E., et al. (2017). Exosomal microRNA signatures in multiple sclerosis reflect disease status. Sci. Rep. 7, 1-10. doi: 10.1038/s41598-017-14301-3

Frühbeis, C., Fröhlich, D., and Krämer-Albers, E.-M. (2012). Emerging roles of exosomes in neuron-glia communication. Front. Physiol. 3:119. doi: 10.3389/fphys.2012.00119

Galazka, G., Mycko, M., Selmaj, I., Raine, C., and Selmaj, K. (2017). Multiple sclerosis: serum-derived exosomes express myelin proteins. Mult. Scler. J. 24:135245851769659. doi: 10.1177/1352458517696597

García-Romero, N., Carrión-Navarro, J., Esteban-Rubio, S., Lázaro-Ibáñez, E., Peris-Celda, M., Alonso, M. M., et al. (2017). DNA sequences within glioma-derived extracellular vesicles can cross the intact blood-brain barrier and be detected in peripheral blood of patients. Oncotarget 8, 1416-1428. doi: $10.18632 /$ oncotarget. 13635

Gardiner, C., Di Vizio, D., Sahoo, S., Théry, C., Witwer, K. W., Wauben, M., et al. (2016). Techniques used for the isolation and characterization of extracellular vesicles: results of a worldwide survey. J. Extracell. Vesicles 5:32945. doi: 10.3402/jev.v5.32945

Gatson, N. N., Williams, J. L., Powell, N. D., McClain, M. A., Hennon, T. R., Robbins, P. D., et al. (2011). Induction of pregnancy during established EAE halts progression of CNS autoimmune injury via pregnancy-specific serum factors. J. Neuroimmunol. 230, 105-113. doi: 10.1016/j.jneuroim.2010.09.010

Geraci, F., Ragonese, P., Barreca, M. M., Aliotta, E., Mazzola, M. A., Realmuto, S., et al. (2018). Differences in intercellular communication during clinical relapse and gadolinium-enhanced MRI in patients with relapsing remitting multiple sclerosis: a study of the composition of extracellular vesicles in cerebrospinal fluid. Front. Cell. Neurosci. 12:418. doi: 10.3389/fncel.2018.00418

Giovannelli, I., Martelli, F., Repice, A., Massacesi, L., Azzi, A., and Giannecchini, S. (2015). Detection of JCPyV microRNA in blood and urine samples of multiple sclerosis patients under natalizumab therapy. J. Neurovirol. 21, 666-670. doi: 10.1007/s13365-015-0325-3

Goetzl, E. J., Boxer, A., Schwartz, J. B., Abner, E. L., Petersen, R. C., Miller, B. L., et al. (2015). Altered lysosomal proteins in neural-derived plasma exosomes in preclinical Alzheimer disease. Neurology 85, 40-47. doi: 10.1212/WNL.0000000000001702

Goetzl, E. J., Elahi, F. M., Mustapic, M., Kapogiannis, D., Pryhoda, M., Gilmore, A., et al. (2019). Altered levels of plasma neuron-derived exosomes and their cargo proteins characterize acute and chronic mild traumatic brain injury. FASEB J. 33, 5082-5088. doi: 10.1096/fj.201802319R

Goetzl, E. J., Mustapic, M., Kapogiannis, D., Eitan, E., Lobach, I. V., Goetzl, L., et al. (2016). Cargo proteins of plasma astrocyte-derived exosomes in Alzheimer's disease. FASEB J. 30, 3853-3859. doi: 10.1096/fj.201600756R

Goetzl, E. J., Schwartz, J. B., Abner, E. L., Jicha, G. A., and Kapogiannis, D. (2018). High complement levels in astrocyte-derived exosomes of Alzheimer disease. Ann. Neurol. 83, 544-552. doi: 10.1002/ana.25172

Harbo, H. F., Gold, R., and Tintoré, M. (2013). Sex and gender issues in multiple sclerosis. Ther. Adv. Neurol. Disord. 6, 237-248. doi: $10.1177 / 1756285613488434$

Havrdova, E., Galetta, S., Hutchinson, M., Stefoski, D., Bates, D., Polman, C. H., et al. (2009). Effect of natalizumab on clinical and radiological disease activity in multiple sclerosis: a retrospective analysis of the Natalizumab Safety and Efficacy in Relapsing-Remitting Multiple Sclerosis (AFFIRM) study. Lancet Neurol. 8, 254-260. doi: 10.1016/S1474-4422(09)70021-3

Hernandez-Oller, L., Seras-Franzoso, J., Andrade, F., Rafael, D., Abasolo, I., Gener, P., et al. (2020). Extracellular vesicles as drug delivery systems in cancer. Pharmaceutics 12:1146. doi: 10.3390/pharmaceutics12121146

Hornung, S., Dutta, S., and Bitan, G. (2020). CNS-derived blood exosomes as a promising source of biomarkers: opportunities and challenges. Front. Mol. Neurosci. 13:38. doi: 10.3389/fnmol.2020.00038

Jeppesen, D. K., Fenix, A. M., Franklin, J. L., Higginbotham, J. N., Zhang, Q., Zimmerman, L. J., et al. (2019). Reassessment of exosome composition. Cell 177, 428-445.e18. doi: 10.1016/j.cell.2019.02.029

Karimi, N., Cvjetkovic, A., Jang, S. C., Crescitelli, R., Hosseinpour Feizi, M. A., Nieuwland, R., et al. (2018). Detailed analysis of the plasma extracellular vesicle proteome after separation from lipoproteins. Cell. Mol. Life Sci. 75, 2873-2886. doi: 10.1007/s00018-018-2773-4

Karussis, D., Karageorgiou, C., Vaknin-Dembinsky, A., Gowda-Kurkalli, B., Gomori, J. M., Kassis, I., et al. (2010). Safety and immunological effects of mesenchymal stem cell transplantation in patients with multiple sclerosis and amyotrophic lateral sclerosis. Arch. Neurol. 67, 1187-1194. doi: 10.1001/archneurol.2010.248

Kibria, G., Ramos, E., Lee, K., Bedoyan, S., Huang, S., Samaeekia, R., et al. (2016). A rapid, automated surface protein profiling of single circulating exosomes in human blood. Sci. Rep. 6:36502. doi: 10.1038/srep36502

Kim, H.-S., Choi, D.-Y., Yun, S. J., Choi, S.-M., Kang, J. W., Jung, J. W., et al. (2012). Proteomic analysis of microvesicles derived from human mesenchymal stem cells. J. Proteome Res. 11, 839-849. doi: 10.1021/pr200682z

Kim, H. J., and Park, J.-S. (2017). Usage of human mesenchymal stem cells in cell-based therapy: advantages and disadvantages. Dev. Reprod. 21, 1-10. doi: 10.12717/DR.2017.21.1.001

Kimura, K., Hohjoh, H., Fukuoka, M., Sato, W., Oki, S., Tomi, C., et al. (2018). Circulating exosomes suppress the induction of regulatory $\mathrm{T}$ cells via let-7i in multiple sclerosis. Nat. Commun. 9:2406. doi: 10.1038/s41467-01702406-2

Kowal, J., Arras, G., Colombo, M., Jouve, M., Morath, J. P., Primdal-Bengtson, B., et al. (2016). Proteomic comparison defines novel markers to characterize heterogeneous populations of extracellular vesicle subtypes. Proc. Natl. Acad. Sci. U.S.A. 113, E968-977. doi: 10.1073/pnas.1521230113

Lässer, C., Jang, S. C., and Lötvall, J. (2018). Subpopulations of extracellular vesicles and their therapeutic potential. Mol. Aspects Med. 60, 1-14. doi: 10.1016/j.mam.2018.02.002

Lassmann, H. (2019). Pathogenic mechanisms associated with different clinical courses of multiple sclerosis. Front. Immunol. 9:3116. doi: 10.3389/fimmu.2018.03116

Lebrun-Frenay, C., Kantarci, O., Siva, A., Sormani, M. P., Pelletier, D., Okuda, D. T., et al. (2020). Radiologically isolated syndrome: 10-year risk estimate of a clinical event. Ann. Neurol. 88, 407-417. doi: 10.1002/ana.25799

Lee, Y. X. F., Johansson, H., Wood, M. J. A., and El Andaloussi, S. (2019). Considerations and implications in the purification of extracellular vesicles a cautionary tale. Front. Neurosci. 13:1067. doi: 10.3389/fnins.2019.01067 
Li, S., Xu, J., Qian, J., and Gao, X. (2020). Engineering extracellular vesicles for cancer therapy: recent advances and challenges in clinical translation. Biomater. Sci. 8, 6978-6991. doi: 10.1039/d0bm01385d

Li, X., Zhang, Y., Yan, Y., Ciric, B., Ma, C.-G., Chin, J., et al. (2017). LINGO1 -Fc-transduced neural stem cells are effective therapy for chronic stage experimental autoimmune encephalomyelitis. Mol. Neurobiol. 54, 4365-4378. doi: 10.1007/s12035-016-9994-z

Li, Z., Liu, F., He, X., Yang, X., Shan, F., and Feng, J. (2019). Exosomes derived from mesenchymal stem cells attenuate inflammation and demyelination of the central nervous system in EAE rats by regulating the polarization of microglia. Int. Immunopharmacol. 67, 268-280. doi: 10.1016/j.intimp.2018.12.001

Lombardi, M., Parolisi, R., Scaroni, F., Bonfanti, E., Gualerzi, A., Gabrielli, M., et al. (2019). Detrimental and protective action of microglial extracellular vesicles on myelin lesions: astrocyte involvement in remyelination failure. Acta Neuropathol. 138, 987-1012. doi: 10.1007/s00401-019-02049-1

Lötvall, J., Hill, A. F., Hochberg, F., Buzás, E. I., Di Vizio, D., Gardiner, C., et al. (2014). Minimal experimental requirements for definition of extracellular vesicles and their functions: a position statement from the International Society for Extracellular Vesicles. J. Extracell. Vesicles 3:26913. doi: $10.3402 /$ jev.v3.26913

Lublin, F. D., Reingold, S. C., Cohen, J. A., Cutter, G. R., Sørensen, P. S., Thompson, A. J., et al. (2014). Defining the clinical course of multiple sclerosis. Neurology 83, 278-286. doi: 10.1212/WNL.0000000000000560

Lunavat, T. R., Cheng, L., Kim, D.-K., Bhadury, J., Jang, S. C., Lässer, C., et al. (2015). Small RNA deep sequencing discriminates subsets of extracellular vesicles released by melanoma cells - evidence of unique microRNA cargos. RNA Biol. 12, 810-823. doi: 10.1080/15476286.2015.1056975

Manna, I., Iaccino, E., Dattilo, V., Barone, S., Vecchio, E., Mimmi, S., et al. (2018). Exosome-associated miRNA profile as a prognostic tool for therapy response monitoring in multiple sclerosis patients. FASEB J. 32, 4241-4246. doi: 10.1096/fj.201701533R

Marcos-Ramiro, B., Oliva Nacarino, P., Serrano-Pertierra, E., Blanco-Gelaz, M. Á., Weksler, B. B., Romero, I. A., et al. (2014). Microparticles in multiple sclerosis and clinically isolated syndrome: effect on endothelial barrier function. $B M C$ Neurosci. 15:110. doi: 10.1186/1471-2202-15-110

Mathivanan, S., and Simpson, R. (2009). ExoCarta: a compendium of exosomal proteins and RNA. Proteomics 9, 4997-5000. doi: 10.1002/pmic.200900351

Moyano, A. L., Li, G., Boullerne, A. I., Feinstein, D. L., Hartman, E., Skias, D., et al. (2016). Sulfatides in extracellular vesicles isolated from plasma of multiple sclerosis patients. J. Neurosci. Res. 94, 1579-1587. doi: 10.1002/jnr.23899

Muhsin-Sharafaldine, M.-R., and McLellan, A. D. (2018). Tumor-derived apoptotic vesicles: with death they do part. Front. Immunol. 9:957. doi: 10.3389/fimmu.2018.00957

Muralidharan-Chari, V., Clancy, J., Plou, C., Romao, M., Chavrier, P., Raposo, G., et al. (2009). ARF6-regulated shedding of tumor cell-derived plasma membrane microvesicles. Curr. Biol. 19, 1875-1885. doi: 10.1016/j.cub.2009.09.059

Muralidharan-Chari, V., Clancy, J. W., Sedgwick, A., and D'Souza-Schorey, C. (2010). Microvesicles: mediators of extracellular communication during cancer progression. J. Cell Sci. 123, 1603-1611. doi: 10.1242/jcs.064386

Mustapic, M., Eitan, E., Werner, J. K., Berkowitz, S. T., Lazaropoulos, M. P., Tran, J., et al. (2017). Plasma extracellular vesicles enriched for neuronal origin: a potential window into brain pathologic processes. Front. Neurosci. 11:278. doi: $10.3389 /$ fnins. 2017.00278

Nigro, A., Colombo, F., Casella, G., Finardi, A., Verderio, C., and Furlan, R. (2016). Myeloid extracellular vesicles: messengers from the demented brain. Front. Immunol. 7:17. doi: 10.3389/fimmu.2016.00017

Niwald, M., Migdalska-Sek, M., Brzeziańska-Lasota, E., and Miller, E. (2017). Evaluation of selected microRNAs expression in remission phase of multiple sclerosis and their potential link to cognition, depression, and disability. J. Mol. Neurosci. 63, 275-282. doi: 10.1007/s12031-017-0977-y

Nordberg, M., Eaton, E., Gonzalez Toledo, E., Harris, M., Chalamidas, K., McGee, J., et al. (2011). The effects of high dose interferon- $\beta 1 \mathrm{a}$ on plasma microparticles: correlation with MRI parameters. J. Neuroinflamm. 8:43. doi: 10.1186/1742-2094-8-43

Onódi, Z., Pelyhe, C., Terézia Nagy, C., Brenner, G. B., Almási, L., Kittel, Á., et al. (2018). Isolation of high-purity extracellular vesicles by the combination of iodixanol density gradient ultracentrifugation and bind-elute chromatography from blood plasma. Front. Physiol. 9:1479. doi: 10.3389/fphys.2018.01479
Paul, D., Baena, V., Ge, S., Jiang, X., Jellison, E. R., Kiprono, T., et al. (2016). Appearance of claudin-5+ leukocytes in the central nervous system during neuroinflammation: a novel role for endothelial-derived extracellular vesicles. J. Neuroinflamm. 13:292. doi: 10.1186/s12974-016-0755-8

Pieragostino, D., Cicalini, I., Lanuti, P., Ercolino, E., di Ioia, M., Zucchelli, M., et al. (2018). Enhanced release of acid sphingomyelinase-enriched exosomes generates a lipidomics signature in CSF of multiple sclerosis patients. Sci. Rep. 8:3071. doi: 10.1038/s41598-018-21497-5

Pieragostino, D., Lanuti, P., Cicalini, I., Cufaro, M. C., Ciccocioppo, F., Ronci, M., et al. (2019). Proteomics characterization of extracellular vesicles sorted by flow cytometry reveals a disease-specific molecular cross-talk from cerebrospinal fluid and tears in multiple sclerosis. J. Proteomics 204:103403. doi: 10.1016/j.jprot.2019.103403

Prada, I., Gabrielli, M., Turola, E., Iorio, A., D’Arrigo, G., Parolisi, R., et al. (2018). Glia-to-neuron transfer of miRNAs via extracellular vesicles: a new mechanism underlying inflammation-induced synaptic alterations. Acta Neuropathol. 135, 529-550. doi: 10.1007/s00401-017-1803-x

Pusic, A. D., Pusic, K. M., and Kraig, R. P. (2014). What are exosomes and how can they be used in multiple sclerosis therapy? Expert Rev. Neurother. 14, 353-355. doi: 10.1586/14737175.2014.890893

Ransohoff, R. M., Hafler, D. A., and Lucchinetti, C. F. (2015). Multiple sclerosis-a quiet revolution. Nat. Rev. Neurol. 11, 134-142. doi: 10.1038/nrneurol.2015.14

Raposo, G., and Stoorvogel, W. (2013). Extracellular vesicles: exosomes, microvesicles, and friends. J. Cell Biol. 200, 373-383. doi: $10.1083 /$ jcb. 201211138

Record, M., Subra, C., Silvente-Poirot, S., and Poirot, M. (2011). Exosomes as intercellular signalosomes and pharmacological effectors. Biochem. Pharmacol. 81, 1171-1182. doi: 10.1016/j.bcp.2011.02.011

Rekker, K., Saare, M., Roost, A. M., Kubo, A.-L., Zarovni, N., Chiesi, A., et al. (2014). Comparison of serum exosome isolation methods for microRNA profiling. Clin. Biochem. 47, 135-138. doi: 10.1016/j.clinbiochem.2013.10.020

Riazifar, M., Mohammadi, M. R., Pone, E. J., Yeri, A., Lässer, C., Segaliny, A. I., et al. (2019). Stem cell-derived exosomes as nanotherapeutics for autoimmune and neurodegenerative disorders. ACS Nano 13, 6670-6688. doi: 10.1021/acsnano.9b01004

Sáenz-Cuesta, M., Alberro, A., Muñoz-Culla, M., Osorio-Querejeta, I., FernandezMercado, M., Lopetegui, I., et al. (2018). The first dose of fingolimod affects circulating extracellular vesicles in multiple sclerosis patients. Int. J. Mol. Sci. 19:2448. doi: 10.3390/ijms19082448

Sáenz-Cuesta, M., Osorio-Querejeta, I., and Otaegui, D. (2014). Extracellular vesicles in multiple sclerosis: what are they telling us? Front. Cell. Neurosci. 8:100. doi: $10.3389 /$ fncel.2014.00100

Scolding, N. J., Morgan, B. P., Houston, W. A., Linington, C., and Campbell, A. K. (1989). Vesicular removal by oligodendrocytes of membrane attack complexes formed by activated complement. Nature 339, 620-622. doi: 10.1038/339620a0

Selmaj, I., Mycko, M. P., Raine, C. S., and Selmaj, K. W. (2017). The role of exosomes in CNS inflammation and their involvement in multiple sclerosis. J. Neuroimmunol. 306, 1-10. doi: 10.1016/j.jneuroim.2017.02.002

Shi, M., Sheng, L., Stewart, T., Zabetian, C. P., and Zhang, J. (2019). New windows into the brain: central nervous system-derived extracellular vesicles in blood. Prog. Neurobiol. 175, 96-106. doi: 10.1016/j.pneurobio.2019.01.005

Stuffers, S., Brech, A., and Stenmark, H. (2009). ESCRT proteins in physiology and disease. Exp. Cell Res. 315, 1619-1626. doi: 10.1016/j.yexcr.2008.10.013

Szatanek, R., Baj-Krzyworzeka, M., Zimoch, J., Lekka, M., Siedlar, M., and Baran, J. (2017). The methods of choice for extracellular vesicles (EVs) characterization. Int. J. Mol. Sci. 18:1153. doi: 10.3390/ijms18061153

Takov, K., Yellon, D. M., and Davidson, S. M. (2019). Comparison of small extracellular vesicles isolated from plasma by ultracentrifugation or sizeexclusion chromatography: yield, purity and functional potential. J. Extracell. Vesicles 8:1560809. doi: 10.1080/20013078.2018.1560809

Tang, Y.-T., Huang, Y.-Y., Zheng, L., Qin, S.-H., Xu, X.-P., An, T.-X., et al. (2017). Comparison of isolation methods of exosomes and exosomal RNA from cell culture medium and serum. Int. J. Mol. Med. 40, 834-844. doi: $10.3892 / \mathrm{ijmm} .2017 .3080$

Théry, C., Amigorena, S., Raposo, G., and Clayton, A. (2006). Isolation and characterization of exosomes from cell culture supernatants and biological fluids. Isol. Charact. Exosomes Cell Cult. Supernatants Biol. 30, 3.22.1-3.22.29. doi: $10.1002 / 0471143030$.cb0322s30 
Théry, C., Witwer, K. W., Aikawa, E., Alcaraz, M. J., Anderson, J. D., Andriantsitohaina, R., et al. (2018). Minimal information for studies of extracellular vesicles 2018 (MISEV2018): a position statement of the International Society for Extracellular Vesicles and update of the MISEV2014 guidelines. J. Extracell. Vesicles 7:1535750. doi: 10.1080/20013078.2018.1535750

Thompson, A. G., Gray, E., Heman-Ackah, S. M., Mäger, I., Talbot, K., Andaloussi, S. E., et al. (2016). Extracellular vesicles in neurodegenerative disease - pathogenesis to biomarkers. Nat. Rev. Neurol. 12, 346-357. doi: $10.1038 /$ nrneurol.2016.68

Tkach, M., and Théry, C. (2016). Communication by extracellular vesicles: where we are and where we need to go. Cell 164, 1226-1232. doi: 10.1016/j.cell.2016.01.043

Tricarico, C., Clancy, J., and D'Souza-Schorey, C. (2016). Biology and biogenesis of shed microvesicles. Small GTPases. 8, 220-232. doi: 10.1080/21541248.2016.1215283

van der Pol, E., Sturk, A., van Leeuwen, T., Nieuwland, R., Coumans, F., and ISTH-SSC-VB Working Group (2018). Standardization of extracellular vesicle measurements by flow cytometry through vesicle diameter approximation. $J$. Thromb. Haemost. 16, 1236-1245. doi: 10.1111/jth.14009

van der Vos, K. E., Abels, E. R., Zhang, X., Lai, C., Carrizosa, E., Oakley, D., et al. (2016). Directly visualized glioblastoma-derived extracellular vesicles transfer RNA to microglia/macrophages in the brain. Neuro Oncol. 18, 58-69. doi: 10.1093/neuonc/nov244

van Niel, G., D'Angelo, G., and Raposo, G. (2018). Shedding light on the cell biology of extracellular vesicles. Nat. Rev. Mol. Cell Biol. 19, 213-228. doi: $10.1038 / \mathrm{nrm} .2017 .125$

Verderio, C., Muzio, L., Turola, E., Bergami, A., Novellino, L., Ruffini, F., et al. (2012). Myeloid microvesicles are a marker and therapeutic target for neuroinflammation. Ann. Neurol. 72, 610-624. doi: 10.1002/ana. 23627

Villa, F., Quarto, R., and Tasso, R. (2019). Extracellular vesicles as natural, safe and efficient drug delivery systems. Pharmaceutics 11:557. doi: 10.3390/pharmaceutics11110557

Weiner, H. L. (2008). A shift from adaptive to innate immunity: a potential mechanism of disease progression in multiple sclerosis. J. Neurol. 255(Suppl. 1), 3-11. doi: 10.1007/s00415-008-1002-8

Welton, J. L., Loveless, S., Stone, T., von Ruhland, C., Robertson, N. P., and Clayton, A. (2017). Cerebrospinal fluid extracellular vesicle enrichment for protein biomarker discovery in neurological disease; multiple sclerosis. J. Extracell. Vesicles 6:1369805. doi: 10.1080/20013078.2017.13 69805

Wheway, J., Latham, S. L., Combes, V., and Grau, G. E. R. (2014). Endothelial microparticles interact with and support the proliferation of T cells. J. Immunol. 193, 3378-3387. doi: 10.4049/jimmunol.1303431

Wickman, G., Julian, L., and Olson, M. F. (2012). How apoptotic cells aid in the removal of their own cold dead bodies. Cell Death Differ. 19, 735-742. doi: $10.1038 /$ cdd. 2012.25

Williams, J. L., Gatson, N. N., Smith, K. M., Almad, A., McTigue, D. M., and Whitacre, C. C. (2013). Serum exosomes in pregnancy-associated immune modulation and neuroprotection during CNS autoimmunity. Clin. Immunol. Orlando Fla 149, 236-243. doi: 10.1016/j.clim.2013.04.005
Willms, E., Cabañas, C., Mäger, I., Wood, M. J. A., and Vader, P. (2018) Extracellular vesicle heterogeneity: subpopulations, isolation techniques, and diverse functions in cancer progression. Front. Immunol. 9:738. doi: 10.3389/fimmu.2018.00738

Xu, X., Lai, Y., and Hua, Z.-C. (2019). Apoptosis and apoptotic body: disease message and therapeutic target potentials. Biosci. Rep. 39:BSR20180992. doi: 10.1042/BSR20180992

Yamout, B., Hourani, R., Salti, H., Barada, W., El-Hajj, T., Al-Kutoubi, A., et al. (2010). Bone marrow mesenchymal stem cell transplantation in patients with multiple sclerosis: a pilot study. J. Neuroimmunol. 227, 185-189. doi: 10.1016/j.jneuroim.2010.07.013

Yáñez,-Mó, M., Siljander, P. R.-M., Andreu, Z., Zavec, A. B., Borràs, F. E., Buzas, E. I., et al. (2015). Biological properties of extracellular vesicles and their physiological functions. J. Extracell. Vesicles 4:27066. doi: 10.3402/jev.v4.27066

Yu, L., Yang, F., Jiang, L., Chen, Y., Wang, K., Xu, F., et al. (2013). Exosomes with membrane-associated TGF- $\beta 1$ from gene-modified dendritic cells inhibit murine EAE independently of MHC restriction. Eur. J. Immunol. 43, 2461-2472. doi: 10.1002/eji.201243295

Zappulli, V., Friis, K. P., Fitzpatrick, Z., Maguire, C. A., and Breakefield, X. O. (2016). Extracellular vesicles and intercellular communication within the nervous system. J. Clin. Invest. 126, 1198-1207. doi: 10.1172/JCI81134

Zhang, Q., Fu, L., Liang, Y., Guo, Z., Wang, L., Ma, C., et al. (2018). Exosomes originating from MSCs stimulated with TGF- $\beta$ and IFN $-\gamma$ promote Treg differentiation. J. Cell Physiol. 233, 6832-6840. doi: 10.1002/jcp.26436

Zhang, Y., Han, J.-J., Liang, X.-Y., Zhao, L., Zhang, F., Rasouli, J., et al. (2018). miR-23b suppresses leukocyte migration and pathogenesis of experimental autoimmune encephalomyelitis by targeting CCL7. Mol. Ther. 26, 582-592. doi: 10.1016/j.ymthe.2017.11.013

Zhuang, X., Xiang, X., Grizzle, W., Sun, D., Zhang, S., Axtell, R. C., et al. (2011). Treatment of brain inflammatory diseases by delivering exosome encapsulated anti-inflammatory drugs from the nasal region to the brain. Mol. Ther. J. Am. Soc. Gene Ther. 19, 1769-1779. doi: 10.1038/mt.2011.164

Ziemssen, T., Akgün, K., and Brück, W. (2019). Molecular biomarkers in multiple sclerosis. J. Neuroinflamm. 16:272. doi: 10.1186/s12974-019$1674-2$

Zinger, A., Latham, S. L., Combes, V., Byrne, S., Barnett, M. H., Hawke, S. et al. (2016). Plasma levels of endothelial and B-cell-derived microparticles are restored by fingolimod treatment in multiple sclerosis patients. Mult. Scler. J. 22, 1883-1887. doi: 10.1177/1352458516636959

Conflict of Interest: The authors declare that the research was conducted in the absence of any commercial or financial relationships that could be construed as a potential conflict of interest.

Copyright (c) 2021 Marostica, Gelibter, Gironi, Nigro and Furlan. This is an openaccess article distributed under the terms of the Creative Commons Attribution License (CC BY). The use, distribution or reproduction in other forums is permitted, provided the original author(s) and the copyright owner(s) are credited and that the original publication in this journal is cited, in accordance with accepted academic practice. No use, distribution or reproduction is permitted which does not comply with these terms. 